ACTA AGROBOTANICA

Vol. 46, z. 1 - 1993

73-81

\title{
Changes in endogenous cytokinin-like substances in onion bulbs (Allium cepa L.) cv. Sochaczewska during storage
}

\author{
ELŻBIETA KIELAK, MARIA BIELINSKA - CZARNECKA
}

\begin{abstract}
Laboratory of Plant Physiology, Institute of Applied Biology, Agricultural and Teachers University,
\end{abstract} Prusa 12, 08-110 Siedlce, Poland

(Received: November 6, 1989)

\begin{abstract}
Onion bulbs cv. Sochaczewska were dried under an umbrella roof until October 15 th or November 15 th and thereafter stored in a cold room at $0-1^{\circ} \mathrm{C}$ until May 15 th. During 4 years of the experiment, the activity of cytokinin-like substances was determined each month during storage. The cytokinin activity showed two to three peaks: at the beginning of storage, in January-February (in one year in December) and at the end of the storage period. No clear correlation was found between cytokinin activity and bulb rooting or sprouting. The lenght of the drying period occasionally influenced the height of cytokinin activity peaks and displaced the moment of their appearance. Weather conditions in particular years seem to be the main factor influencing the changes in cytokinin activity.
\end{abstract}

\section{INTRODUCTION}

Three periods may be distinguished in onion storage: rest, dormancy and regrowth (I s e $\mathrm{n}$ b e r g et al., 1974). During rest, the cellular activities of cytokinin-like substances are at very low levels (T h o m a s, 1969, I s e $\mathrm{n}$ b e $\mathrm{r} g$ et al., 1974). Also S y r a n ova and Turdce va (1983) noted during this period low cytokinins levels in bulbs of Juno coerulea, and $S$ y $r \mathrm{t}$ a $\mathrm{n}$ o $\mathrm{va}$ and $\mathrm{R} \mathrm{a} \mathrm{c} \mathrm{h} \mathrm{i} \mathrm{m} \mathrm{b} \mathrm{a} \mathrm{je} v$ (1983) in bulbs of Korolkowia seversovii. Dormancy is characterized by renewed cellular activity and an increase in cytokinin content (I s e $\mathrm{n} \mathrm{be} \mathrm{r} \mathrm{g}$ and $\mathrm{T} \mathrm{h}$ o $\mathrm{m}$ a s, 1970, I s e $\mathrm{n}$ b e r $\mathrm{g}$ et al., 1974, I s e $\mathrm{n}$ b e $\mathrm{r}$ g, 1978). The regrowth stage is characterized by formation of sheath and leaf initials accompanied by rapid cell division (I s e nb e r g et al., 1974; I s e $n$ b e r g, 1978). During this period $R$ a c h i m b a j e v 
and $\mathrm{S}$ o $\mathrm{l} \mathrm{o} \mathrm{m}$ i n a (1975) noted high levels of cytokinins in growing organs, in central parts of onions. According to R e e s (1972), cytokinin-like substances participate in the initiations of flower buds or in formation of the progeny of onions.

Several authors (H c r n cr, 1972; A b d e l- R a h man and I s e b e r g, 1974; T h o $\mathrm{m}$ a s, 1981) postulate that cytokinin-like substances are the most effective of all stimulators in the induction of onion bulb sprouting. Gibberellins and auxins do not induce this processes. The aim of the present paper was to observe cytokinin activity in onion bulbs during storage in relation to their dormancy, root formation and sprouting. To stimulate the methods used by growers, the bulbs were subjected to two periods of drying (shorter and longer). Since the behaviour of bulbs in storage is greatly dependent on climate, the observations were carried out over four seasons.

\section{MATERIAL AND METHODS}

The investigations were performed with onion bulbs cv. Sochaczewska from mid October 1979 till mid May 1983.

Onions were cultivated in 1979, 1981 and 1982 at Guzów near Skierniewice (central Poland) on black soil and in 1980 at Leszkowice near Głogów (southwestern Poland) on alluvial soil.

Weather conditions were defferent in particular years (Fig. 1).

The year 1979 was relatively warm and not too wet in the first months of vegetation, cold and rainy in August and September.

The year 1980 was relatively dry (except June and September) and relatively warm. In 1981 - June and July and also October and November were humid. Starting from July temperatures were below the many-years average. The year 1982 was dry and warm except for June-July.

Experiments were performed in two variants, onions were dried under an umbrella roof: I - till October 15 th and II - November $15 \mathrm{th}$. Thereafter onion bulbs from both variants were stored in a cold room at $0-1^{\circ} \mathrm{C}$ until May $15 \mathrm{th}$. Sampling was repeated every month. At each sampling hormones were extracted from plugs $1,5 \mathrm{~cm}$ in diameter taken from the center of bulbs with the base plate.

$100 \mathrm{~g}$ of fresh material were homogenized and extracted twice with $70 \%$ methanol. The combined methanol fractions were evaporated and the remaining water-soluble residue was acidified with $3 \mathrm{~N}$ HCL to $\mathrm{pH} 3,0$. It was then passed through an Amberlite IR-120 $\mathrm{H}^{+}$column, washed with water and eluted with $500 \mathrm{~cm}^{3} 5 \mathrm{~N} \mathrm{NH}_{4} \mathrm{OH}$. The ammonia fraction was reduced to $30 \mathrm{~cm}^{3}$ volume, alkalized with $3 \mathrm{~N} \mathrm{NaOH}$ to $\mathrm{pH} 8,2$ and shaken three times with butanol $(1: 1)$. The butanol fraction, after cvaporation to dryness, was dissolved in $2 \mathrm{~cm}^{3}$ of $70 \%$ methanol and used for thin-layer separation on Kiesegel $60 \mathrm{~F} 254$ in a mixture of butanol : acetic 
acid : water $(12: 3: 5)$. After drying, the respective zones of silica gel were scraped off from the plates and the material was extracted with water for 24 hours. Eluates were bioassayed using the Amaranthus test, as described by Kö h l er and C on r a d (1966).
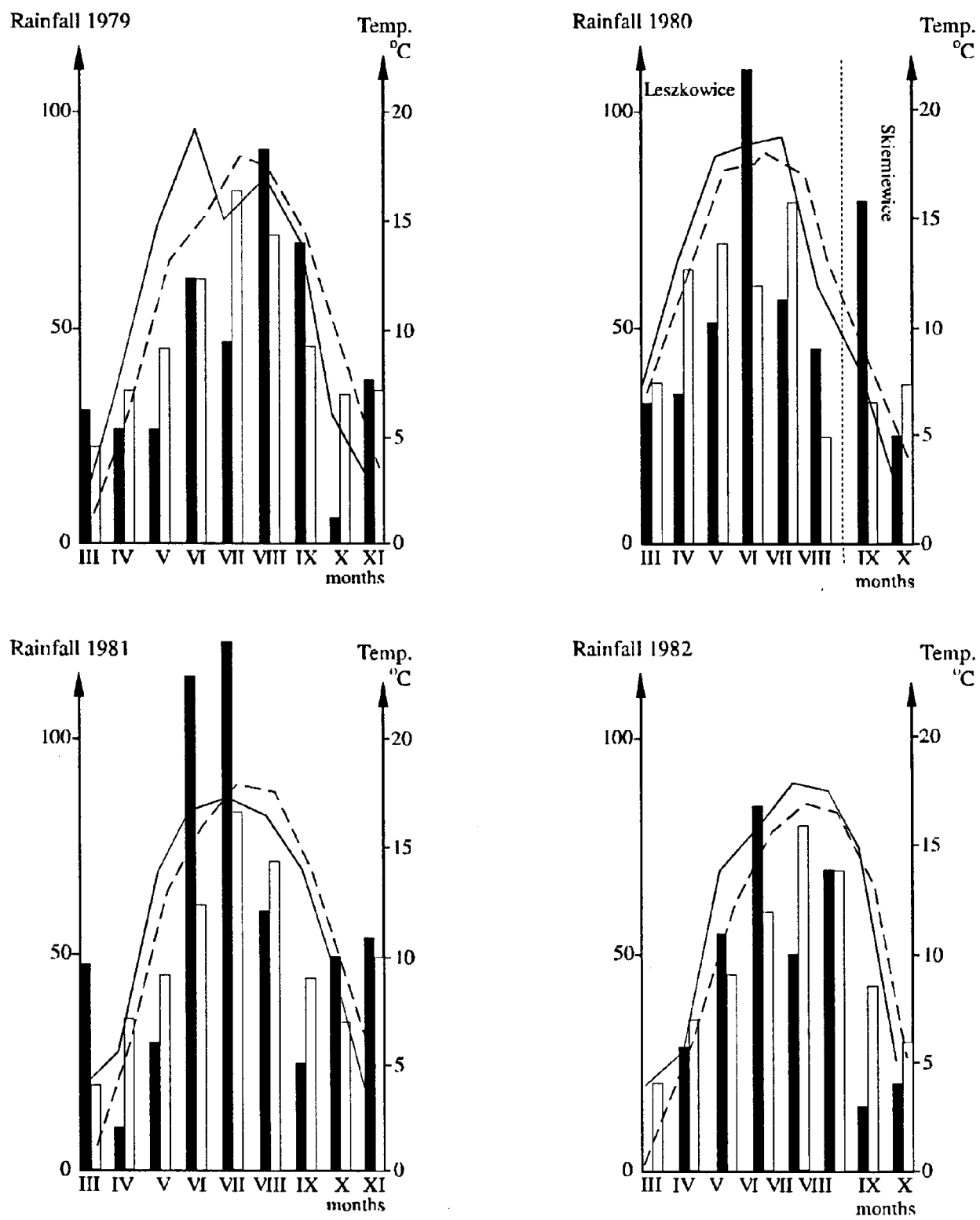

Fig. 1. Average monthly air temperatures and precypitations in successive experimental seasons in relation to long-term average air temperatures 1921-1960- - and total rainfall $\square$ for Skierniewice 


\section{RESULT AND DISCUSSION}

In most experimental seasons (exept 1981/82 - Fig. 2C) endogenous cytokinin-like substances appeared in onion bulbs of both variants at the beginning of storage, i.e. in October and November (Fig. 2A, 2B, 2D). The present observation is in agreement with those of other authors (I s e $\mathrm{n}$ b e r $\mathrm{g}$ et al., 1974; I s e $\mathrm{n}$ b e r $\mathrm{g}$ and T h o m a s, 1970; I s e $\mathrm{n}$ b e $\mathrm{r} g, 1978$ ). The increase of cytokinin activity is related to intense mitotic divisions before onion sprouting ( $\mathrm{R}$ e e s, 1972). T h o m a s (1969) and I s e $\mathrm{n}$ b e r $\mathrm{g}$ (1978) suggested that the increase of mitotic activity in this period indicates that the onion bulbs have finished their rest and begun their dormancy. $\mathrm{H} \mathrm{a} \mathrm{b} \mathrm{d} \mathrm{a} \mathrm{s} \mathrm{(1983)} \mathrm{observed} \mathrm{an} \mathrm{elongating} \mathrm{top} \mathrm{of} \mathrm{the} \mathrm{inflorescence} \mathrm{shoot} \mathrm{in} \mathrm{onion}$ (Allium cepa L.) already in November which was preceded by rather intensive cell divisions and elongation.

In the present experiment, increased cytokinin activity was also observed in other periode of storage, i. e. generally in February (Fig. 2A, 2B and Fig. 2C - in this last case, especially in onions dried shorter). T h o $\mathrm{m}$ a s and I s e n b e r g (1972) observed only one peak of cytokinin activity (the end of January), followed by a decrease until the end of the storage period. In looking for analogies with other plant material it may be mentioned that in potato tubers, three peaks of cytokinin activity during storage (B a n a ś et al., 1988) are usually found. B or kow s ka and $\mathrm{R} \mathrm{u} \mathrm{d} \mathrm{n} \mathrm{i} \mathrm{c} \mathrm{k} \mathrm{i} \mathrm{(1975)} \mathrm{observed} \mathrm{increased} \mathrm{cytokinin} \mathrm{activity} \mathrm{in} \mathrm{apple} \mathrm{seeds} \mathrm{after} \mathrm{five}$ weeks of stratification followed by a decrease. High levels of cytokinins were also observed at the end of storage in three vegetation seasons, i.e. in April and May (Fig. 2A, 2B and 2D - in onions dried longer).

The pattern of cytokinin changes during the 1981/1982 season (Fig. 2C) was very different from that in other seasons. We did not find cytokinin activity at the beginning of storage in onions dried for a shorter time. In February we noted very high cytokinin levels in onions dried shorter and very low activity in onions dried longer. During this season we did not observe cytokinin activity in onions at the end of storage. This is probably due to the very high precipitation during the vegetation period in June and July. The time-course of inhibitor and gibberellin activity observed during this season was also quite specific (K i e la k et al., 1988; K i e l a k and $\mathrm{B}$ i e l i ń s k - C z a rn e cka, 1991).

One can observe some negative correlation between cytokinin and inhibitor activity (comp. Fig. 2A, 2C, 2D and analogical figures for inhibitors - K i e l a k et al., 1988): in three seasons, increased cytokinin activity was accompanied by a decrease in inhibitor activity. A similiar negative correlation was observed in onions by T h o m a s and I s e n be r g (1972). Our study, however, showed more than one maximum of cytokinin and inhibitor activities during storage and was continued over several seasons. There are data showing that exogenous abscisic acid impedes the biosynthesis of cytokinin during stratification of apple seeds ( $\mathrm{R} \mathrm{u} \mathrm{d} \mathrm{n} \mathrm{i} \mathrm{c} \mathrm{k} \mathrm{i} \mathrm{and}$ B o r k ow s k a, 1973). The antagonistic activity of cytokinins and inhibitors in $\alpha$-amylase and RNA synthesis was also reported ( $\mathrm{K} \mathrm{h}$ a $\mathrm{n}, 1975)$. 

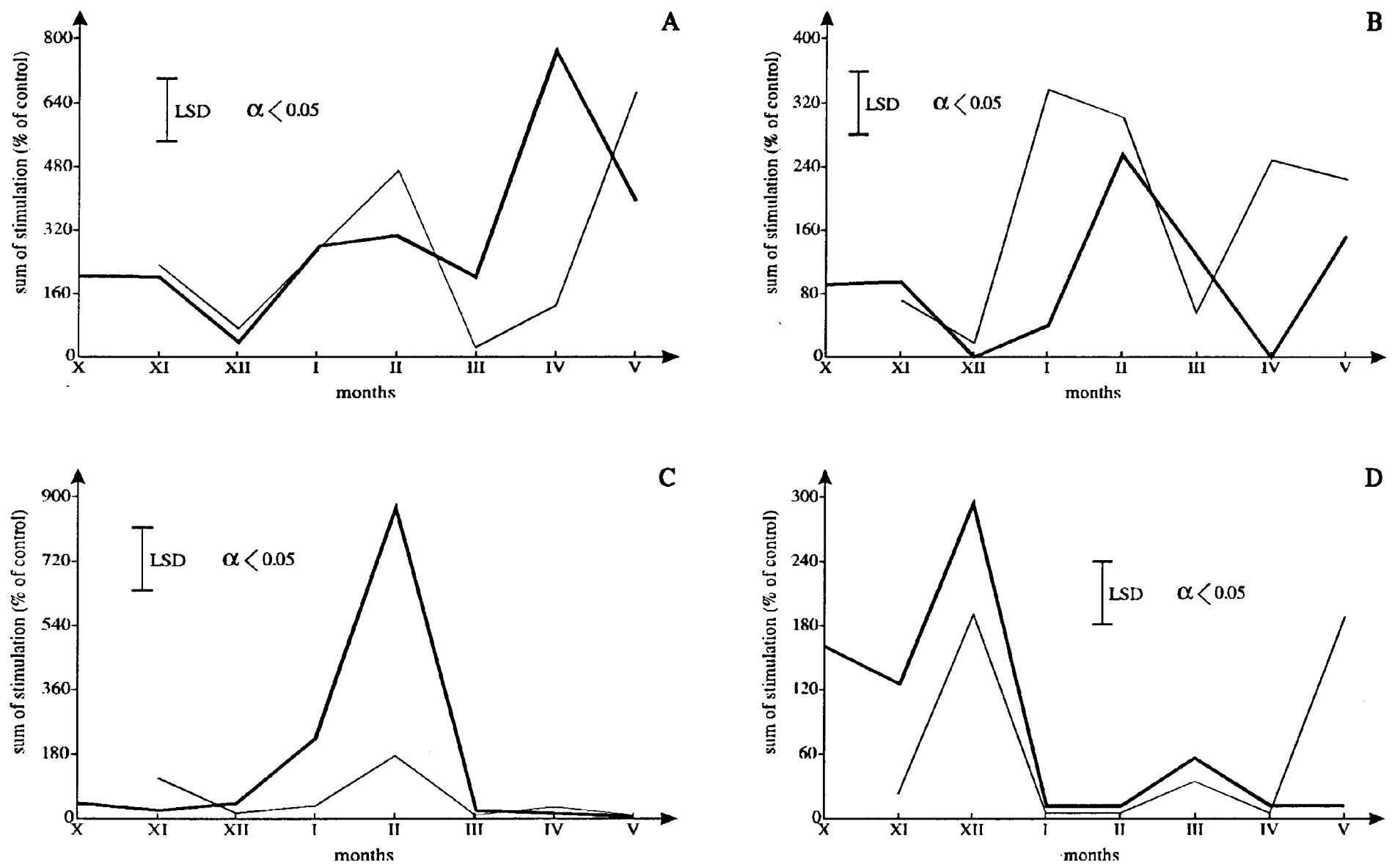

Fig. 2. Changes of endogenous cytokinin-like substances in onion:

drying to 15 October,

drying to 15 November; A - 1979/80 season, B - 1980/81 season, C - 1981/82 season. D - 1982/83 season 
In the present study, no explicit correlation between the lenght of onion drying and cytokinin activity was found. The picture changed from year to year. For example, at the beginning of storage in the 1979/1980 season in February much higher cytokinin activity in onions dried for a longer period was observed. On the other hand, higher activity in March and April was observed in onions dried for a longer period of time (Fig. 2B). In the 1980/81 season we observed higher cytokinin activity in all storage periods (except November and March) in onions dried for a longer period of time (Fig. 2B). The 1981/1982 season (Fig. 2C) was exceptional concerning weather conditions, and concerning the pattern of cytokinin changes. During this season the difference in cytokinin activity between the onions dried for longer and shorter periods was very significant (especially in February's maximum). The activity of cytokinins in onions dried shorter was higher. Measurements of rooting and sprouting in the 1981/1982 (Fig. 3A, 4A) and 1982/1983 seasons (Fig. 3B, 4B) showed that at the begenning of storage, onion bulbs are mostly dormant. In respect to 1981/1982, when October and November were very humid (Fig. 1), longer drying, which in these conditions was ineffective, resulted in more intensive rooting (Fig. 3A). No such clear differences were observed for sprouting (Fig. 4A).
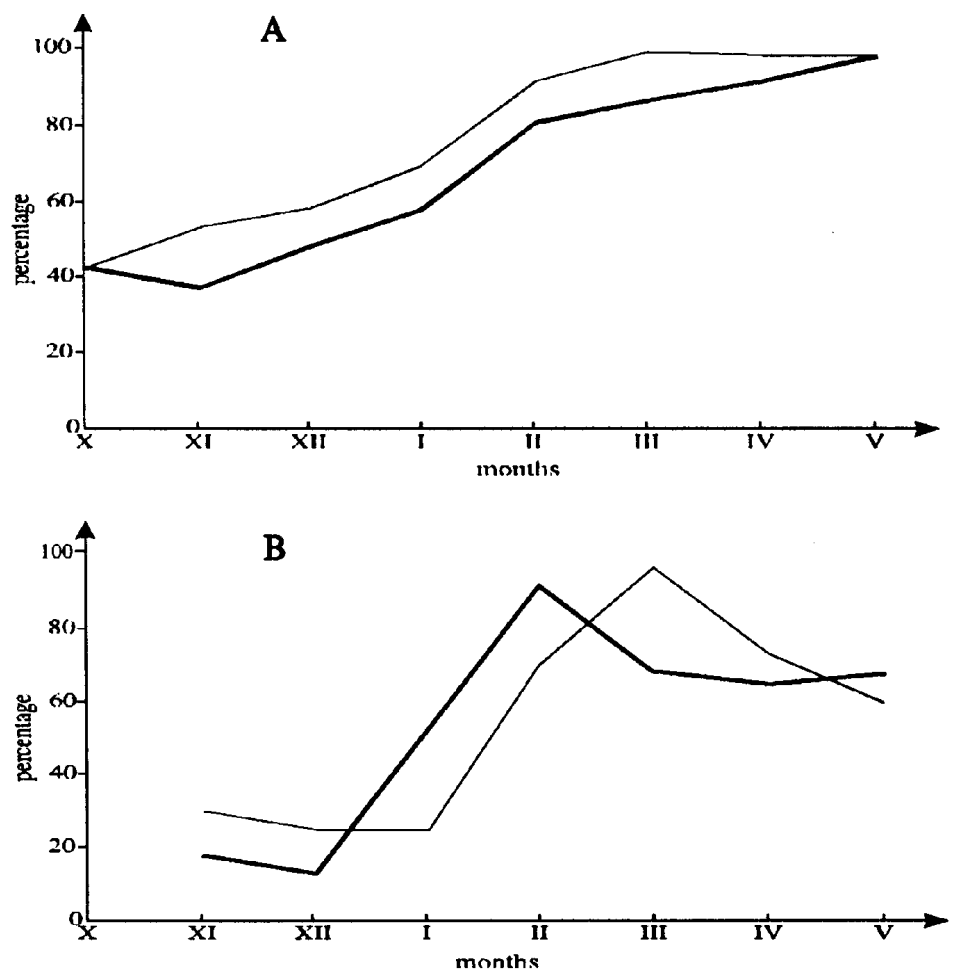

Fig. 3. Percentage of onions with roots after 5 days of growth: 

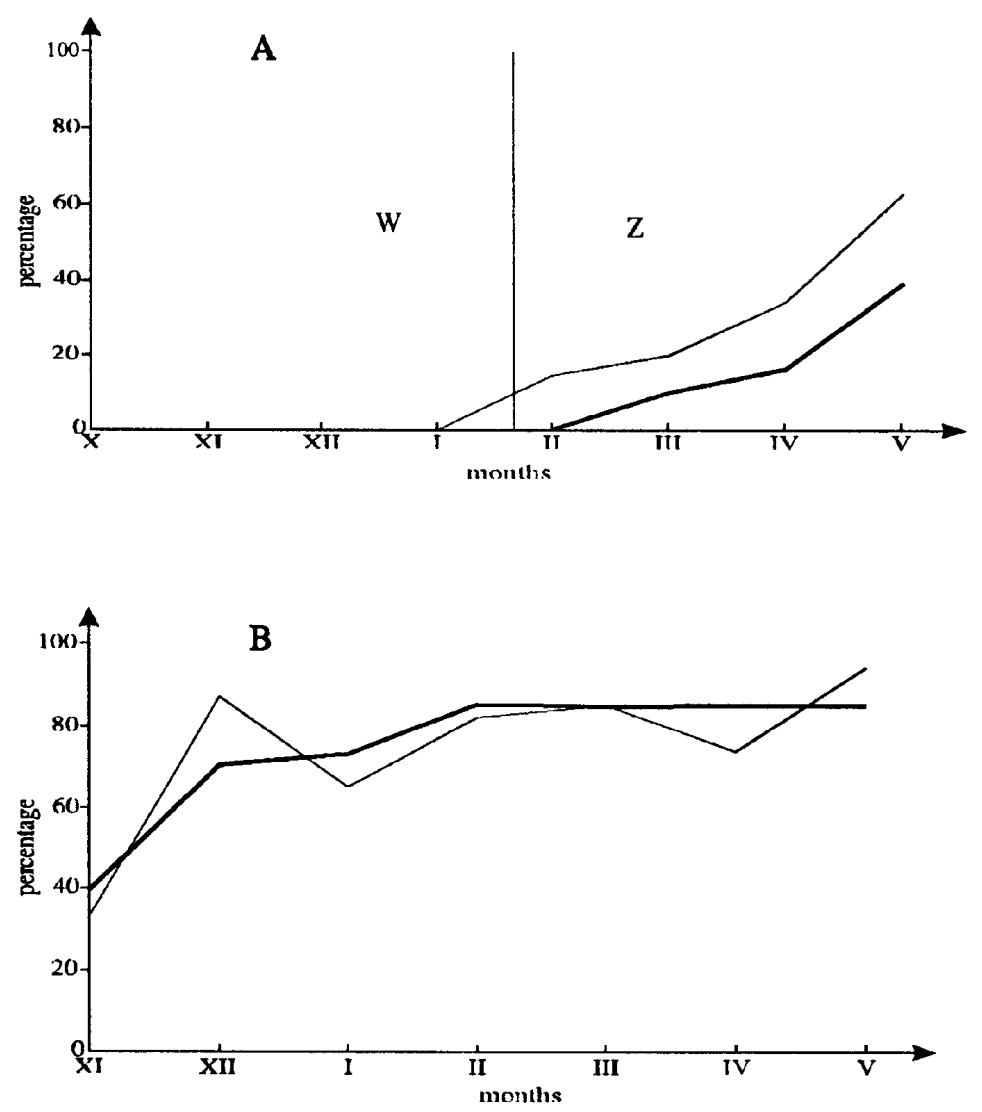

Fig. 4. Percentage of sprouting onion after 5 days of growth drying to 15 October, - drying to 15 November; A - 1981/82 season, B - 1982/83 season, $\mathrm{W}$ - leaves inside of onion, $\mathrm{Z}$ - leaves outside of onion

\section{CONCLUSIONS}

1. The activity of cytokinins in onion bulbs changed markedly during storage showing two to three peaks separated by periods of low activity. The high of particular peaks differed markedly in different years.

2. No distinct correlation was found between cytokinin activity and such phenomenae as bulb rooting or sprouting.

3. During three seasons changes in cytokinin and inhibitor activities showed a tendency towards negative correlation but in one season there was a tendency for positive correlation (comparing the results of the present paper with those of $\mathrm{K}$ i e $1 \mathrm{a} \mathrm{k}$ et al., 1988). 
4. The lenght of the drying period occasionally influenced the hight of cytokinin activity peaks and displaced the moment of their appereance.

5 . The weather conditions in particular years seem to be the main factor influencing the time-course of cytokinin activity changes as well as the process of drying.

\section{REFERENCES}

A b d e l- R a h m a n M., I s e $\mathrm{n}$ b e r g F. M. R., 1974. The role of exogenous plant regulators in the dormancy of onion bulbs. J. agric. Sci. 82: 113-116.

Banaś A., Bielińska-Czarnecka M., Klocek J, 1988. Cytokinin activity in potato tubers during storage. Ziemniak: 15-28.

B ork ow sk a B., R u d n i ck i R. M., 1975. Changes in the levels of cytokinins in apple seeds during stratification. Fruit Sci. Rep., 2 (2): 1-16.

$\mathrm{H}$ a b d a s H., 1983. Anatomiczno-cytologiczne zmiany w tkankach cebuli wywolane promieniowaniem gamma. I Ogólnopolska Konferencja Biologii Komórki. Kraków: 64.

H e r n e r R., 1972. Chemical and physical factors which effect quality and postharvest deterioriation of vegetables. Ann. Rep. Dept. Hort., Michigan Sta. Univ., 41.

I s e n b e r g F. M. R., 1978. Onions cry for proper storage. Am. Veg. Grower. 26 (3): 28, 54.

I s e n ber g F. M. R., Thom as T.H., 1970. Onion dormancy. Ann. Rep. Nat. Veg. Res. Sta., Wellesbourne, Warwick: $72-73$.

Is enberg F.M. R., Thomas T.H., Abdel-Rahman M., Pendergrass A., Carroll I. C., How e 11 L., 1974. The role of natural growth regulators in rest, dormancy and regrowth of vegetables during winter storage. XIXth Inter. Hort. Congress., Warszawa.

I se nberg F.M. R., Thomas T.H., Pendergras s N., Abdel- Rah man M., 1974. Hormone and histological defferences between normal and maleic hydrazide treated onions stored over winter. Acta Hort. 38: 95-125.

K h a n A. A., 1975. Primary, preventive and permissive roles of hormones in plant systems. Bot. Rev. 41 (4): 391-399.

$\mathrm{K}$ i e la k E., B i e l i ń s k a - C z a r n e c k a M., 1991. Changes in endogenous gibberellin-like substances in onion bulbs (Allium cepa L.) cv. Sochaczewska during storage. Acta Agrobot. 44 (1,2): 65-71.

$\mathrm{K}$ i e lak E., B i e l i ńs k a - C zar n e cka M., Róż y cka H., 1988. Changes in endogenous growth inhibitors in onion bulbs (Allium cepa L.) cv. Sochaczewska during storage. Acta Agrobot. 41 (2): 265-274.

Kö h l e r K. H., Con rad K., 1966. Ein quantitavier phytokinin test. Biol. Rundschau. 4 (1): 36-37.

R a c h i m b a j e v I. R., S o l o m in a V.F., 1975. Prirodnyje cytokininy i pokoj lukovic tjulpana. Fizjologija Rast. 22 (3): 615-618.

Re es A. R., 1972. The growth of bulbs. Academic Press, London and New York.

R u d n i cki R., B ork ow ska B., 1973. The effect of abscisic acid on the cytokinin level in apple seeds during stratification. Prace Inst. Sadownictwa. Ser. E. 3: 291-295.

S y r a tow a G. A., R a c h i m b a j e v I. R., 1983. Fitogormony i pokoj lukovicnych rastienij. Nauka, Alma-Ata: 6-90.

S y r t a n ova G. A., Turd ce va V.M., 1983. Endogennye citokininy v lukovicach junony goluboj. Izw. Akad. Nauk KazSSR. Ser. biol.: 2604-2683.

Th o m a s T. H., 1969. The role of growth substances in the regulation of onion bulb dormancy. J. Exp. Bot. 20: 124-137.

Th o m a s T. H., 1981. Hormonal control of dormancy in relation to postharvest horticulture. Ann. Appl. Biol. 98 (3): 531-538.

Th o m a s T.H., I s e n b e r g F. M. R., 1972. Hormone physiology of onion bulbs during dormancy. Exper. Hortic. 23: 48-51. 


\title{
Zmiany endogennych substancji cytokininopodobnych w cebuli (Allium cepa L.) odm. Sochaczewska podczas przechowywania
}

\author{
Streszczenie
}

Cebulę odm. Sochaczewska dosuszano pod wiatą do 15 października lub 15 listopada, a nastẹpnie przechowy wano w komorze chłodniczejo temp. $0-1^{\circ} \mathrm{C}$ do 15 maja. Oznaczenia substancji cytokininopodobnych były wykonywane co miesiąc, w ciągu 4-ch sezonów przechowalniczych. Obserwowano dwa-trzy okresy wysokiej aktywności substancji cytokininopodobnych: na początku okresu przechowywania, w styczniu-lutym ( $w$ jednym sezonie $w$ grudniu) i na końcu okresu przechowywania. Nie stwierdzono jednoznacznej zależności pomiędzy aktywnością cytokininową a wyrastaniem korzeni i szczypioru. Dhugość okresu dosuszania wpływała niekiedy na aktywność cytokinin i moment jej występowania. Warunki pogody w poszczególnych sezonach wydają się być głównym czynnikiem wywierającym wpływ na zniany aktywności cytokinin. 